Brief Report

Am Acad Dermatol 1993;29(2 Pt 1):242-248.

5. Kaylani S, Theos AJ, Pressey JG. Treatment of infantile hemangiomas with sirolimus in a patient with PHACE syndrome. Pediatr Dermatol 2013;30:e194-e197.

6. Dodds M, Maguiness S. Topical sirolimus therapy for epidermal nevus with features of acanthosis nigricans. Pediatr
Dermatol 2019;36:554-555.

7. Cinar SL, Kartal D, Bayram AK, Canpolat $M$, Borlu M, Ferahbas A, et al. Topical sirolimus for the treatment of angiofibromas in tuberous sclerosis. Indian J Dermatol Venereol Leprol 2017;83:27-32.

\title{
Comments on "Unusual Presentation of Subcutaneous Phaeohyphomycosis by Alternaria alternate" by Lee et al.
}

\author{
Jong Bin Park, Kee Suck Suh, Min Soo Jang \\ Department of Dermatology, Kosin University College of Medicine, Busan, Korea
}

\section{Dear Editor:}

Lee et al. ${ }^{1}$ recently reported an interesting case entitled, "Unusual presentation of subcutaneous phaeohyphomycosis by Alternaria alternate."

Phaeohyphomycosis is the general term used to describe infections due to dematiaceous or darkly pigmented fungi. This is histologic definition of a disease process that can be caused by many different organisms and can have multiple different clinical presentations ${ }^{2}$. Over 100 species and 60 genera of dematiaceous fungi have been implicated in human diseases. Bipolaris, Phialophora, Alternaria, and Exophiala are the fungi responsible for phaeohyphomycosis ${ }^{2}$. The distinguishing feature of these species is presence of melanin in Athe cell walls, which imparts the dark color to their conidia or spores and hyphae. In addi-

Received November 19, 2019, Accepted for publication November 19, 2019

Corresponding author: Min Soo Jang, Department of Dermatology, Kosin University College of Medicine, 262 Gamcheon-ro, Seo-gu, Busan 49267, Korea. Tel: 82-51-990-6145, Fax: 82-51-990-3041, E-mail: ksderm77@ unitel.co.kr

ORCID: https://orcid.org/0000-0002-5686-0830

This is an Open Access article distributed under the terms of the Creative Commons Attribution Non-Commercial License (http://creativecommons. org/licenses/by-nc/4.0) which permits unrestricted non-commercial use, distribution, and reproduction in any medium, provided the original work is properly cited.

Copyright (c) The Korean Dermatological Association and The Korean Society for Investigative Dermatology tion, the colonies are typically brown to black in color. The diagnosis of phaeohyphomycosis is confirmed by histopathological examination of clinical specimens and careful gross and microscopic examination of cultures $^{3}$. In this case report, gross and microscopic findings of culture were not described. To diagnose phaeohyphomycosis by histological examination, it is necessary to identify the presence of melanin in the fungal wall. However, Fig. 2A, $B$ do not show any pigmented hyphae or spores in Hematoxylin and Eosin (H\&E)-stained sections. In Fig. 2D, the presence of melanin pigment in the fungal wall is identified only by Fontana-Masson staining. The authors have stated, "A specific melanin stain such as Fontana-Masson can be used to identify the dark pigmented fungi accurately." We would like to comment that use of Fontana-Masson melanin stain is not recommended to identify dematiaceous fungi ${ }^{1}$.

The production of melanin is not unique to dematiaceous fungi. West et al. ${ }^{4}$ used Fontana-Masson stain in tissue sections of 132 cases of culture-proven mycoses to classify the staining patterns of common fungal pathogens. Many non-dematiaceous organisms, including Zygomycetes, Aspergillus, and Fusarium in addition to Cryptococcus, showed positive results. Interestingly, only $63 \%$ cases diagnosed with dematiaceous fungi stained positive with FontanaMasson. The authors suggested that Fontana-Masson staining should not be relied upon as proof that an organism is dematiaceous. Elston ${ }^{5}$ stated, "Pigment can sometimes be 
inconspicuous in the hyphal wall. However, using FontanaMasson melanin stain to identify lightly pigmented dematiaceous fungi is problematic, as some non-pigmented molds (including zygomycetes and dermatophytes) will stain."

Alternaria species (spp.) are well-known causative agents of phaeohyphomycosis. This case report may lead to the misunderstanding that phaeohyphomycosis can be diagnosed by the positive finding of Fontana-Masson staining. However, careful interpretation with H\&E-stained sections is required to identify dematiaceous fungi to diagnose phaeohyphomycosis.

\section{CONFLICTS OF INTEREST}

The authors have nothing to disclose.

\section{FUNDING SOURCE}

None.

\section{DATA SHARING STATEMENT}

Research data are not shared.

\section{ORCID}

Jong Bin Park, https://orcid.org/0000-0002-3547-421X

Kee Suck Suh, https://orcid.org/0000-0002-4998-0914

Min Soo Jang, https://orcid.org/0000-0002-5686-0830

\section{REFERENCES}

1. Lee JY, Hyun M, Kim HA, Ryu SY. Unusual presentation of subcutaneous phaeohyphomycosis by Alternaria alternate. Ann Dermatol 2019;31:563-566.

2. Hinshaw MA, Longley BJ. Fungal diseases. In: Elder DE, Elenitsas R, Rosenbach M, Murphy GF, Rubin Al, Xu X, editors. Lever's histopathology of the skin. 11th ed. Philadelphia: Wolters Kluwer, 2014:727-760.

3. Revankar SG. Dematiaceous fungi. Mycoses 2007;50:91-101.

4. West KL, Proia AD, Puri PK. Fontana-Masson stain in fungal infections. J Am Acad Dermatol 2017;77:1119-1125.

5. Elston DM. Fungal infections. In: Elston DM, Ferringer T, Ko CJ, Peckham S, High WA, DiCaudo DJ, editors. Dermatopathology. 3rd ed. Philadelphia: Elsevier, 2019:306-320. 